\title{
Diffusion of responsibility in group work: Social loafing
}

\author{
Şule Betül Tosuntaş \\ Bursa Uludağ University, Turkey
}

\begin{abstract}
Determining the effect of social loafing behaviors on the performance of individual and group members in the context of group work is considered important. The aim of this research is to examine the effect of social loafing and cyberloafing behaviors on group work. The effect of social loafing and cyberloafing on group studies was examined on the basis of a structural equation model. For this purpose, the study was designed using a causal research design. Using criterion sampling, one of the purposeful sampling methods, 846 undergraduate students studying at a state university participated in the study. The data of the study were collected using social loafing, cyberloafing, self-evaluation and group evaluation measurement tools. The data of the study were analyzed using $t$ test, correlation analysis, simple linear regression, multiple regression and path analysis. As a result of the analysis of the data, it was seen that individual social loafing, cyberloafing and self-evaluations differed according to gender. In addition, when social loafing, cyberloafing, self-evaluation and group evaluation were analyzed according to group formation, there were statistically significant differences in favor of the student-created groups. Group size was found to be positively correlated with social loafing behaviors, but no significant relationship was found with task visibility. The structural equation model created within the scope of the study was tested with path analysis and it was concluded that individual loafing behaviors had an effect on self-assessment, and that group social loafing behaviors had an effect on group evaluations. Group size and group formation can be taken into consideration in order to make effective and productive group studies in higher education. These results may guide future studies on addressing the factors associated with social loafing in the context of group work, which has an important place in the learning-teaching process.
\end{abstract}

Keywords: Social loafing; Cyberloafing; Diffusion of responsibility; Evaluation

Article History: Submitted 29 July 2020; Revised 14 November 2020; Published online 13 December 2020

\section{Introduction}

In the context of 21st century skills and today's business world, individuals are expected to have communication and collaboration skills. Disposition for teamwork has become one of the most sought-after qualities in the business world. With new approaches in the field of education, the center has shifted from teacher to student. It has emerged that students should be able to take responsibility for learning and actively participate in the process. In the learning-teaching process, by adopting contemporary approaches that focus on the process rather than the product, social, affective and metacognitive gains come to the fore as well as cognitive gains. In the context of

Address of Corresponding Author

Şule Betül Tosuntaş, PhD, Bursa Uludağ University, Faculty of Education, Görükle Campus, 16059 Nilüfer, Turkey.

$\triangle$ sbtosuntas@uludag.edu.tr

0000-0002-0731-6505

How to cite: Tosuntaş, Ş. B. (2020). Diffusion of responsibility in group work: Social loafing. Journal of Pedagogical Research, 4(3), 344358. 
cooperative learning, group work can be used as an effective learning strategy at all educational levels. Group work contributes to students in terms of taking responsibility, being tolerant, critical thinking, doing research, developing social skills, and providing self-confidence in accordance with new approaches. Besides its effect on the retention of learning, it is known to increase motivation and help with meaningful learning (Koç Erdamar \& Demirel, 2010). On the other hand, various problems, such as disagreements among group members and not fulfilling their responsibilities, emerge for group work that is not based on cooperative learning principles. What is expected in group work is sharing and positive commitment in accordance with the principles of cooperative learning.

Group work is widely accepted in higher education, and tasks that require students to work in collaboration with small groups are included. It is important to provide self-evaluation and group evaluation opportunities by supporting the active participation of students in the evaluation process during group studies. Traditional approaches aim to classify students according to their level of knowledge and remain limited in terms of evaluating the process (Çepni, 2008). Alternative, complementary or contemporary assessment approaches are based on the principle of considering individual differences and offering various assessment opportunities. In group studies, it is stated that students who do not contribute to group work or contribute more to group work cannot be determined through product-oriented evaluations, which thus cause injustice (Aslanoğlu, 2017). In order not to ignore the process dimension in group work, attention is drawn to self-, peer and group evaluation studies. Studies show that students in higher education are able to evaluate the performance of their peers in group work in an accurate and consistent manner (Sridhran et al., 2018).

\subsection{Self-evaluation and Group Evaluation}

Self-evaluation can be explained as the individual's evaluation of the learning process, learning performance and learning products. It has various benefits such as providing self-control to individuals, increasing their motivation, enabling them to discover their strengths and weaknesses, and ensuring their active participation in the learning process (Sedikides \& Strube, 1997). Group evaluation is used in the evaluation of cooperative learning groups formed to achieve common learning goals. The prominent point in using these evaluations is that the forms can be filled in without worrying about grades. Otherwise, limitations such as biased and unfair evaluations arise. The use of alternative assessment approaches is of significant benefit in terms of determining the performance of the individual and the group in the group work process. However, it is difficult to determine how much an individual contributes to group work during group work. Accordingly, individuals may tend to display behaviors that cause performance loss in group work environments.

\subsection{Social Loafing}

An individual's tendency to reduce his/her effort compared to other individuals performing the same task in the group is defined as social loafing (Latane et al., 1979). Similarly, social loafing is expressed as an individual's less-than-expected effort in group work (Ilgin, 2013). This phenomenon, also known as the Ringelmann effect (Piezon \& Ferree, 2008), is accepted in the context of explaining the productivity losses of individuals working in various communities (George, 1992; Karau \& Williams, 1997). Many studies have concluded that when individuals work collectively, they make less effort than when they work consciously or unconsciously individually (Karau \& Williams, 1997). Social loafing has been conceptualized as a phenomenon that occurs when working in groups and has been described as a social disease (Latane et al., 1979). Possible predictors of social loafing, which are mostly examined in the organizational context, are explained by social impact theory, the collective effort model, arousal reduction, evaluation potential, dispensability of effort, matching of effort, and self-attention (Karau \& Williams, 1993). In the context of organizational behavior, it can directly affect the performance, efficiency and satisfaction of the organization (Duffy \& Shaw, 2000). As the antecedents of social loafing, two 
categories were created, namely individual level and group level. Individual antecedents are commitment, task visibility, distinctiveness and evaluation potential, task attachment, importance and significance of the task, distributive justice, personality traits, culture and gender differences, and organizational citizenship. Group-level antecedents are determined as group size, group cohesion, and perceived social loafing of group members (Liden et al., 2004).

Task visibility is an individual's belief in how much his manager is aware of his or her individual effort at work (George, 1992; Liden et al., 2004). The fact that the effort or contribution of the individual within the group is not identifiable is seen as one of the reasons for social loafing. Perceptions of task visibility vary according to the individual. When the individual thinks that his effort is visible by the manager or can be measured within the group, social loafing behavior may disappear (George, 1992). Task visibility perception will be high when the individual completes the task alone. In cases where he / she completes the task with the group, the increase in the number of employees in the group reduces the individual's distinctiveness, which becomes difficult to evaluate. In this case, it is stated that individuals may consciously or unconsciously tend to withhold their efforts. On the other hand, the individual's perceptions of group members' loafing behaviors also affect their social loafing behaviors. Liden et al. (2004) stated that when group members suspect social loafing by others, they themselves become more prone to loafing. On the other hand, Karau \& Williams (1993) argue that individuals tend to increase their efforts to compensate when their expectations of their colleagues' performance is reduced. According to Kerr (1983) in case of apparent social loafing, the non-loafing individuals either pick up loafers' slack or decline to pick up the slack, inspired by fear of being "taken for a sucker". At the point when individuals are occupied with social loafing, other colleagues will either attempt to avoid additional work or endeavor to get a move on, which respectively increases or mitigates the impact of social loafing (Mulvey \& Klein, 1998). In the studies conducted in the context of education in the literature, there is no clarity on how social loafing behaviors differ when the group is formed by the student or the instructor (Rajaguru et al., 2020).

\subsection{Cyberloafing}

Cyberloafing is one of the loafing behaviors that emerge due to technology being an indispensable part of our daily life. Cyberloafing is defined as individuals' spending unproductive time on the internet during working hours (Ugrin et al., 2008) and using internet access for personal purposes during working hours (Lim, 2002). As mobile devices become widespread and internet access opportunities increase, the frequency of cyberloafing behavior is expected to increase (Akbulut et al., 2016). Although cyberloafing behaviors, like social loafing behaviors, are mostly examined in organizational contexts, there are studies showing that cyberloafing behaviors are also seen at various educational levels (Ergün \& Altun, 2012). In this direction, it can be predicted that the individual can perform cyberloafing during the lesson, as well as exhibit these behaviors during group work.

When the literature is examined, it is seen that the cases of social loafing and cyberloafing are mostly discussed in organizational contexts (Demir Uslu \& Çavuş, 2014; Doğan et al. 2012; Ilgin, 2010; Öneren et al., 2019; Şeşen \& Kahraman, 2014). In the organizational context, the applicability of the reasons, solutions and suggestions to reduce social loafing to the learning-teaching process is not clear (Jassawalla et al., 2009). When the limited studies in the field of education are examined, the personality traits of social loafing (Schippers, 2014; Tok, 2019), predisposition for group work (Albayrak et al., 2012), political skills (Y1ld1z, 2018), group size (Aggarwal \& O'Brien, 2008), and group formation (Aggarwal \& O'Brien, 2008; Rajaguru et al., 2020) are handled together. It is important to consider the phenomenon of social loafing, which is associated with performance as a determinant of success in organizations, in the context of group work, which is frequently used in higher education. In many respects, it is important to know the effect of social loafing in the learning-teaching process and especially in group work. First of all, it is necessary to know the level of social loafing and to take measures in order to ensure efficiency and success in group 
work. In the evaluation process, it becomes difficult to determine the individual success and contribution of the students due to social loafing and a fair evaluation cannot be made. Determining the interactions between individuals' loafing behaviors and self-evaluation and group evaluation will make an important contribution to the examination of social loafing behaviors in education. The aim of this research is to examine the effect of social loafing and cyberloafing behaviors on group work. In this context, the hypotheses tested in the research are as follows.

$H_{1 a} \quad$ Individual and group social loafing and cyberloafing behaviors differ according to gender.

$H_{1 b} \quad$ Self-evaluation and group evaluations differ according to gender.

$\mathrm{H}_{2 a} \quad$ Individual and group social loafing behaviors differ according to group formation.

$\mathrm{H}_{2 b} \quad$ Self-evaluation and group evaluations differ according to group formation.

$\mathrm{H}_{3}$ Individual social loafing behaviors are positively associated with cyberloafing behaviors.

$\mathrm{H}_{4} \quad$ Group size is positively related to individual and group social loafing behaviors.

$\mathrm{H}_{5} \quad$ Task visibility is negatively associated with individual and group social loafing behaviors.

$H_{6} \quad$ Cyberloafing behaviors have a positive effect on individual social loafing behaviors.

$\mathrm{H}_{7} \quad$ Group social loafing behaviors have a positive effect on individual social loafing behaviors.

$\mathrm{H}_{8} \quad$ Group social loafing behaviors have a negative effect on group satisfaction.

$\mathrm{H}_{9} \quad$ Individual social loafing behaviors have a negative effect on self-evaluation.

$H_{10}$ Individual and group social loafing behaviors have a negative effect on group assessment.

$H_{11} \quad$ Group satisfaction has a mediating role in the relationship between group social loafing behaviors and group evaluation.

$H_{12}$ Group evaluation has a positive effect on self-evaluation.

\section{Method}

\subsection{Research Design}

In this study, the aim was to examine the effect of social loafing and cyberloafing on group studies on the basis of a structural equation model. For this purpose, it was planned to consider causeeffect relationships by using a causal research design. In the scope of the research, necessary prerequisites were examined in order to establish a cause-effect relationship between variables, the time sequence between the variables was determined, and it was determined that the prerequisites were met through correlation and regression analysis (Neuman, 2014).

\subsection{Participants}

The participants of this research were undergraduate students studying at a state university. The selection of the participants was carried out using the criterion sampling method. Criterion sampling, which is one of the purposive sampling methods, refers to selecting participants according to pre-determined criteria in line with the purpose of the research. In this study, in order to include the participants in the study, the criterion of "participating in group work during this semester" was adopted. In this context, 846 undergraduate students who met this criterion participated in the study. The average age of the participants was 22.10. The demographic characteristics of the participants are presented in Table 1. 
Table 1

Demographic information of participants

\begin{tabular}{lcccc}
\hline Variables & & 1 & 2 & Total \\
\hline \multirow{3}{*}{ Gender } & $n$ & Male & Female & - \\
& $\%$ & 188 & 658 & 846 \\
& & 22.2 & 77.8 & 100 \\
\hline \multirow{3}{*}{ Age } & $n$ & $18-24$ & $25-$ & - \\
& $\%$ & 724 & 122 & 90 \\
Group Formation & & Student & Instructor & - \\
& $n$ & 653.6 & 193 & 90 \\
\hline
\end{tabular}

\subsection{Data Collection Tools}

The research data were collected through various scales. Information on the measurement tools used in the study is presented in this section.

\subsubsection{Social loafing scales}

Social loafing measurement tools were adapted by Ülke (2006) from Liden et al. (2004) in order to determine the social loafing of individuals' colleagues. In this study, the measurement tool was adapted to indicate group work / homework carried out in the context of the learning-teaching process. The demographic information form included questions related to gender, age, group size, group formation and group satisfaction.

Using the scale items adapted by Ülke (2006), scales were based on determining the individual's own social loafing and the group's views on social loafing. In this respect, two measurement tools were used, namely individual and group social loafing. Each of the measurement tools consists of 13 items in a 5-point Likert-type scale, with scores ranging from "strongly agree" to "never agree". Due to the adaptation work on the measurement tools, the structure of the scales was examined by confirmatory factor analysis. Individual social loafing $(\mathrm{RMSEA}=.07, \mathrm{AGFI}=.92, \mathrm{GFI}=.94, \mathrm{CFI}=$ .93 ) and group social loafing (RMSEA $=.07$, AGFI $=.92, \mathrm{GFI}=.94, \mathrm{CFI}=.97)$ goodness-of-fit indices show that the data are suitable for the proposed theoretical structure. In terms of internal consistency, Cronbach alpha coefficients for individual social loafing and group social loafing were calculated as .78 and .94 , respectively. The validity and reliability coefficients and factor structure of the scales in a one-dimensional structure show that they are appropriate, valid and reliable. Sample items regarding the scales are as follows.

Individual Social Loafing: This refers to the social loafing perceived by the individual during group work.

(1) I avoid taking responsibility in collective task distribution.

(2) I seem to be working if someone else is doing the work.

Group Social Loafing: This refers to the social loafing behaviors of group members during group work.

(1) My groupmates avoid taking responsibility in collective task distribution.

(2) Some of my groupmates seem to be working if someone else is doing the homework, but in fact, they don't do their part.

The group satisfaction items in the demographic information form were considered as a measurement tool, and validity-safety analyses were made. As a result of these analyses, the Group Satisfaction Scale, which was determined to have a single-factor structure, was achieved. As a result of the confirmatory factor analysis, the goodness-of-fit indices of the measurement tool show that the data are suitable for the structure (RMSEA $=.08$, AGFI $=.93$, GFI $=.96, \mathrm{CFI}=.97$ ). With the calculated internal consistency coefficient of .92, it was concluded that the measurement 
tool is reliable. Composed of 3 items, the response scale of the measurement tool ranges from "strongly agree" to "never agree". Sample items of the scale can be listed as follows.

Group Satisfaction: This shows the satisfaction of the individual towards the group with which he continues his group work.

(1) I am happy to work with this group.

(2) I would like to take part in other assignments / tasks with this group.

2.2.2. Task Visibility Scale

The task visibility scale was adapted from George (1992) by Ülke (2006) to determine the perceptions of employees regarding their managers' awareness of their efforts. Similar to the loafing scales, the items of the measurement tool were adapted to reveal the awareness of the relevant instructor of the effort made in homework / group work in the learning-teaching process. The construct validity of the measurement tool was determined by confirmatory factor analysis. Goodness-of-fit indices show that the one-factor structure of the scale was confirmed (RMSEA = $.08, \mathrm{AGFI}=.93, \mathrm{GFI}=.98, \mathrm{CFI}=.98)$. The internal consistency coefficient of the scale was calculated as .87. It is seen that the scale consists of a one-dimensional, 6-item, 5-point Likert-type scale with scores ranging between "strongly agree" and "strongly disagree". Sample items for the scale are as follows:

(1) When a group member make a below-average effort, the lecturer of the lesson is aware of this.

(2) The instructor of the lesson realizes that one of the group members becomes disengaged from the task.

\subsubsection{Cyberloafing scale}

The Cyberloafing Scale developed by Akbulut et al. (2016) was used. This scale consists of 5 subdimensions, namely sharing, shopping, real-time updating, accessing online content and gaming / gambling, and a total of 30 items. The scoring of the scale is of a 5-point Likert type ranging between "always" and "never". In the student sample, the internal consistency coefficient of the total scale was calculated as .92 .

\subsubsection{Self-evaluation and group evaluation}

Self-evaluation and group evaluation forms that ensure active participation of students in the evaluation process were used as evaluation tools. Evaluation tools in the literature were used in the preparation of the forms. With the evaluation tools that were prepared, the aim was for learners to make individual and group evaluations. Each of the evaluation forms consists of 10 items of a 5-point Likert type, with scores ranging between "strongly agree" and "strongly disagree". As a result of the confirmatory factor analysis, it was confirmed that the evaluation forms were one-dimensional, and the individual (.88) and group (.95) internal consistency coefficients were calculated. According to these analyses, the self-evaluation form (RMSEA $=.08$, AGFI $=.92$, GFI $=.95, \mathrm{CFI}=.96)$ and the group evaluation form (RMSEA $=.06$, AGFI $=.94$, $\mathrm{GFI}=.96, \mathrm{CFI}=.98$ ) are two valid and reliable measurement tools. Sample items for the evaluation forms are presented below.

Self-Evaluation: In group work, this refers to the evaluation of the individual's performance in terms of his contribution to group work.

(1) I took appropriate roles in the task sharing.

(2) I listened to the comments and suggestions of my groupmates.

Group Evaluation: In group work, this refers to the evaluation of the performance of the individual in terms of the contribution of his / her colleagues to group work.

(1) They took appropriate roles in task sharing.

(2) They listened to the group's comments and suggestions. 


\subsection{Data Collection}

The data of the research were collected using an online data collection tool. This was achieved by the researcher by sending direct links to the participants. It was stated to the participants who were reached that participation in the research was optional and that they had the right to withdraw from the research at any time. Participants who agreed to participate in the study filled in the data collection tools online. During the data collection process, ethical rules were adhered to and no personal data were collected that would reveal the identity of the participants.

\subsection{Data Analysis}

Sub-dimension and total score means of all scales collected for the purpose of the study were calculated. Outliers were analyzed using a boxplot. Whether the data met the normal distribution conditions was examined according to the kurtosis and skewness coefficients, and it was concluded that the data were normally distributed. Based on the result that the data were distributed normally, using parametric tests, in the context of the demographic variables, difference tests were performed using t-test analysis. Correlation analyses were carried out to determine the relationships between variables. The predictive levels of the determined independent variables on the dependent variable were determined using simple linear regression and multiple regression analysis. The structural equation model showing the relationships between variables was tested using path analysis. The goodness-of-fit indices related to the structural equation model were evaluated on the basis of the values in the literature.

\section{Results}

Various hypotheses were tested in the study, which aimed to examine the effects of university students' social loafing and cyberloafing behaviors on group work. First of all, descriptive statistics for the variables in the study are presented in Table 2. When the average scores of each variable are examined, it is seen that the average scores of individual and group social loafing are at a similar level. Looking at the average scores for evaluation, it can be said that the self-evaluation average score at a higher level than the group evalutaion average score. Kurtosis and skewness values are seen to be between +1.5 and -1.5 , in this study, it can be said that the data are normally distributed (Tabachnick \& Fidell, 2013).

Table 2

Descriptive statistics

\begin{tabular}{lccrrc}
\hline Variables & $n$ & $X$ & SD & Kurtosis & Skewness \\
\hline 1. Individual social loafing & 846 & 2.67 & .35 & -.02 & .28 \\
2. Group social loafing & 846 & 2.77 & .68 & -.63 & .23 \\
3. Cyberloafing & 846 & 2.85 & .81 & -.29 & -.53 \\
4. Perceived task visibility & 846 & 3.14 & .42 & .53 & .04 \\
5. Group satisfaction & 846 & 3.86 & 1.06 & -.32 & -.71 \\
6. Self-evaluation & 846 & 4.33 & .50 & -.61 & -.34 \\
7. Group evaluation & 846 & 4.05 & .76 & -.25 & -.62 \\
\hline
\end{tabular}

Independent samples t-test was conducted to test the hypotheses that express that individual and group social loafing behaviors and cyberloafing behaviors differ by gender. According to the results presented in Table 3, individual social loafing and cyberloafing behaviors differed statistically in favor of female students $[p<.05]$. There was no statistically significant difference between the perceptions of group social loafing behaviors. When the differences in terms of selfevaluation and group evaluation were examined, a significant difference was found in favor of women for self-evaluation. There was no statistically significant difference in terms of group evaluation. According to the findings, hypotheses $\mathrm{H}_{1 \mathrm{a}}$ and $\mathrm{H}_{1 \mathrm{~b}}$ were partially accepted. 
Table 3

t-test findings regarding gender

\begin{tabular}{|c|c|c|c|c|c|c|}
\hline Variables & Gender & $\eta$ & $X$ & $S D$ & $t$ & $p$ \\
\hline \multirow{2}{*}{ 1. Individual social loafing } & Male & 188 & 2.78 & .36 & \multirow{2}{*}{$4.86^{*}$} & \multirow{2}{*}{.00} \\
\hline & Female & 658 & 2.64 & .35 & & \\
\hline \multirow{2}{*}{ 2. Group social loafing } & Male & 188 & 2.73 & .64 & \multirow{2}{*}{-.79} & \multirow{2}{*}{.43} \\
\hline & Female & 658 & 2.78 & .69 & & \\
\hline \multirow{2}{*}{ 3. Cyberloafing } & Male & 188 & 2.97 & .71 & \multirow{2}{*}{$2.29 *$} & \multirow{2}{*}{.02} \\
\hline & Female & 658 & 2.81 & .83 & & \\
\hline \multirow{2}{*}{ 4. Self-evaluation } & Male & 188 & 4.22 & .54 & \multirow{2}{*}{$-3.21^{*}$} & \multirow{2}{*}{.00} \\
\hline & Female & 658 & 4.35 & .49 & & \\
\hline \multirow{2}{*}{ 5. Group evaluation } & Male & 188 & 4.08 & .71 & \multirow{2}{*}{.59} & \multirow{2}{*}{.56} \\
\hline & Female & 658 & 4.05 & .77 & & \\
\hline
\end{tabular}

Hypotheses $\mathrm{H}_{2 a}$ and $\mathrm{H}_{2 b}$, which state that group formation will differentiate individual and group social loafing, cyberloafing behaviors, self-evaluation, and group evaluations, were examined by independent groups t-test. The findings obtained as a result of the analysis show that there were statistically significant differences in favor of student-created groups (see Table 4). In this direction, hypotheses $\mathrm{H}_{2 \mathrm{a}}$ and $\mathrm{H}_{2 \mathrm{~b}}$ were accepted.

Table 4

t-test findings regarding group formation

\begin{tabular}{|c|c|c|c|c|c|c|}
\hline Variables & $\begin{array}{l}\text { Group } \\
\text { formation }\end{array}$ & $\eta$ & $X$ & $s d$ & $t$ & $p$ \\
\hline \multirow{2}{*}{ 1. Individual social loafing } & Student & 653 & 2.64 & .35 & \multirow{2}{*}{$-4.24^{*}$} & \multirow{2}{*}{.00} \\
\hline & Lecturer & 193 & 2.77 & .37 & & \\
\hline \multirow{2}{*}{ 2. Group social loafing } & Student & 653 & 2.73 & .69 & \multirow{2}{*}{$-3.30^{*}$} & \multirow{2}{*}{.00} \\
\hline & Lecturer & 193 & 2.91 & .64 & & \\
\hline \multirow{2}{*}{ 3. Cyberloafing } & Student & 653 & 2.80 & .80 & \multirow{2}{*}{$-2.90^{*}$} & \multirow{2}{*}{.00} \\
\hline & Lecturer & 193 & 3.00 & .82 & & \\
\hline \multirow{2}{*}{ 4. Self-evaluation } & Student & 653 & 4.37 & .48 & \multirow{2}{*}{$4.70^{*}$} & \multirow{2}{*}{.00} \\
\hline & Lecturer & 193 & 4.18 & .54 & & \\
\hline \multirow{2}{*}{ 5. Group evaluation } & Student & 653 & 4.09 & .77 & \multirow{2}{*}{$2.46^{*}$} & \multirow{2}{*}{.00} \\
\hline & Lecturer & 193 & 3.94 & .71 & & \\
\hline
\end{tabular}

$d f=844$

In order to test hypotheses $\mathrm{H}_{3}, \mathrm{H}_{4}$ and $\mathrm{H}_{5}$, the relationships between variables were determined using Pearson's product-moment correlation analysis. When correlation values were examined, a low-level positive correlation was found between individual social loafing, updating and games / gambling sub-dimensions. According to the findings, hypothesis $\mathrm{H}_{3}$ was accepted. When the relationship between group size and loafing behaviors was examined, it was concluded that there was a low-level positive correlation with individual and group social loafing behaviors. Accordingly, hypothesis $\mathrm{H}_{4}$ was accepted. There was no statistically significant relationship between perceived task visibility and individual or group social loafing. In this respect, hypothesis $\mathrm{H}_{5}$ was rejected. 
Table 5

Findings regarding correlations

\begin{tabular}{|c|c|c|c|c|c|c|c|c|c|c|c|c|}
\hline Variables & 1 & 2 & 3 & 4 & 5 & 6 & 7 & 8 & 9 & 10 & 11 & 12 \\
\hline 1. Individual social loafing & - & $.32^{*}$ & .06 & .03 & $.08^{*}$ & .00 & $.12^{*}$ & $.16^{*}$ & .01 & $-.15^{*}$ & $-.32^{*}$ & $-.16^{*}$ \\
\hline 2. Group social loafing & & - & -.06 & -.04 & .02 & $-.07^{*}$ & $-.07^{*}$ & $.14^{*}$ & .02 & $-62^{*}$ & $-.22^{*}$ & $-.65^{*}$ \\
\hline \multicolumn{13}{|l|}{ Cyberloafing } \\
\hline 3.Sharing & & & - & $.60^{*}$ & $.48^{*}$ & $.70^{*}$ & $.31^{*}$ & .05 & .06 & $.09^{*}$ & $.10^{*}$ & .10 \\
\hline 4.Shopping & & & & - & $.38^{*}$ & $.67^{*}$ & $.41^{*}$ & .04 & $.12^{*}$ & .02 & .06 & .02 \\
\hline 5.Updating & & & & & - & $.34^{*}$ & $.23^{*}$ & .04 & .06 & -.04 & .04 & .02 \\
\hline 6.Accessing content & & & & & & - & $.40^{*}$ & $.12^{*}$ & .06 & .02 & .04 & .06 \\
\hline 7. Games/gambling & & & & & & & - & .04 & .04 & -.01 & $-.11^{*}$ & -.01 \\
\hline 8. Group size & & & & & & & & - & .06 & $-.12^{*}$ & $-.10^{*}$ & $-.10^{*}$ \\
\hline 9.Perceived task visibility & & & & & & & & & - & .03 & .02 & .05 \\
\hline 10.Group satisfaction & & & & & & & & & & - & $.34^{*}$ & $.77^{*}$ \\
\hline 11. Self-evaluation & & & & & & & & & & & - & $.47^{*}$ \\
\hline 12.Group evaluation & & & & & & & & & & & & - \\
\hline$\eta=846,{ }^{*} p<.05$ & & & & & & & & & & & & \\
\hline
\end{tabular}

A structural equation model showing the relationships between individual and group social loafing behaviors, cyberloafing, task visibility, group satisfaction, self-assessment and group evaluation was created and tested. Correlation and regression analysis were used to create the model. Path analysis was performed using the observed variables in testing the model.

The goodness of fit for the theoretical model was determined by GFI, AGFI, NFI, RMSEA, $\chi^{2}$ and $\chi^{2}$ / df ratio. The values for the fit of the model are presented in Table 6.

Table 6

Goodness-of-fit indices: Structural equation model of research

\begin{tabular}{lc}
\hline Fit Parameters & Coefficient \\
\hline GFI & .99 \\
AGFI & .97 \\
NFI & .98 \\
RMSEA & .06 \\
$d f$ & 9 \\
$X^{2}$ & 35.59 \\
$\chi^{2} / d f$ & 3.95 \\
\hline
\end{tabular}

As a result of the analysis, it was concluded that the theoretical model formed was compatible with the data obtained. When the path analysis results were examined, it was concluded that the direct effects of one-unit deviation on the variables were statistically significant, and the path coefficients are presented in Figure 1. The direct effect of a unit deviation in individual social loafing variable on self-evaluation is -.39. The direct effects of a unit deviation in group social loafing variable on individual social loafing and group evaluation are .18 and -.37, respectively. In addition, the group social loafing variable has an indirect effect on group evaluation through group satisfaction. 


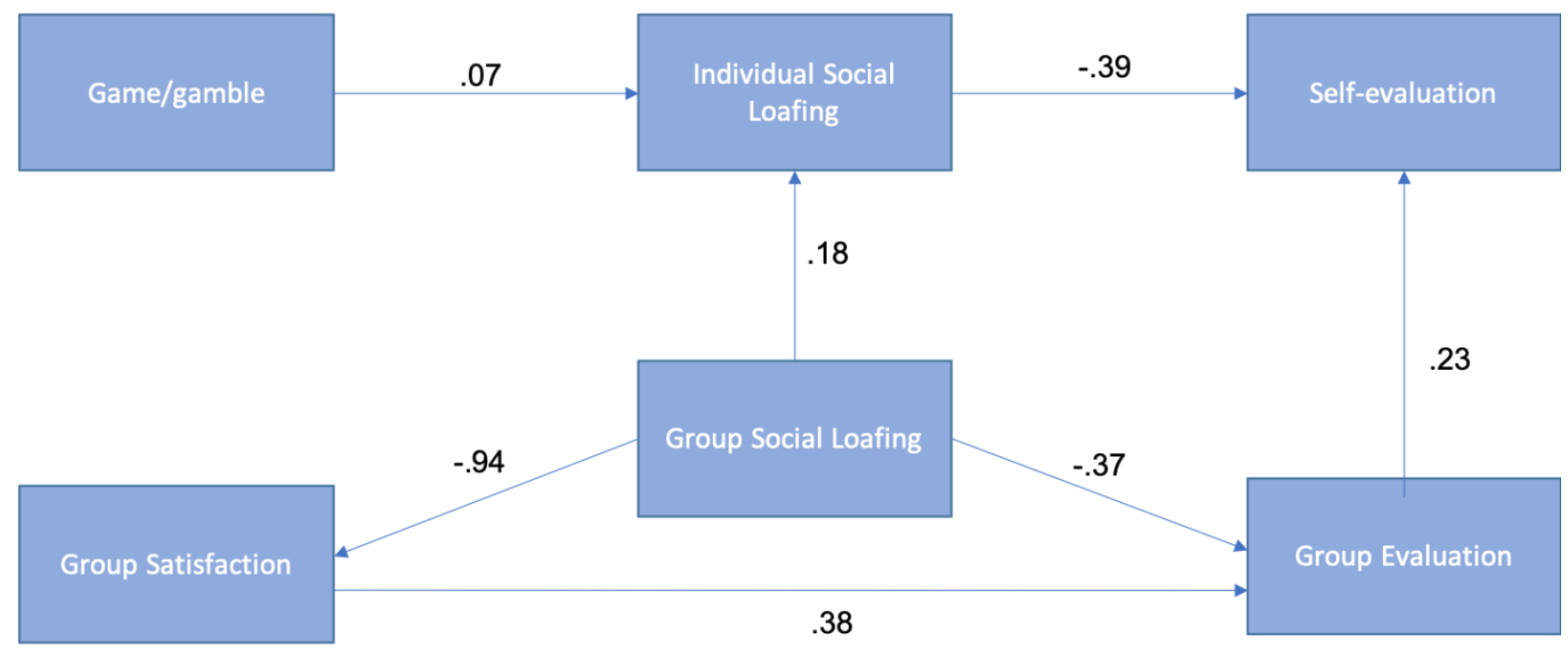

Figure 1. Structural equation model diagram resulting from path analysis

According to the path analysis results, hypotheses $\mathrm{H}_{7}, \mathrm{H}_{8}, \mathrm{H}_{9}, \mathrm{H}_{11}$ and $\mathrm{H}_{12}$ were accepted; hypotheses $\mathrm{H}_{6}$ and $\mathrm{H}_{10}$ were partially accepted. Results regarding the testing of the hypotheses determined within the scope of the research are summarized in Table 7.

Table 7

Summary of hypothesis testing results

\begin{tabular}{|c|c|c|}
\hline Hypotheses & Statements & Results \\
\hline$H_{1 a}$ & $\begin{array}{l}\text { Individual and group social loafing and cyberloafing behaviors differ } \\
\text { according to gender. }\end{array}$ & $\begin{array}{l}\text { Partially } \\
\text { accepted }\end{array}$ \\
\hline$H_{1 b}$ & Self-evaluation and group evaluations differ according to gender. & $\begin{array}{l}\text { Partially } \\
\text { accepted }\end{array}$ \\
\hline$H_{2 a}$ & $\begin{array}{l}\text { Individual and group social loafing behaviors differ according to } \\
\text { group formation. }\end{array}$ & Accepted \\
\hline$H_{2 b}$ & $\begin{array}{l}\text { Self-evaluation and group evaluations differ according to group } \\
\text { formation. }\end{array}$ & Accepted \\
\hline$H_{3}$ & $\begin{array}{l}\text { Individual social loafing behaviors are positively associated with } \\
\text { cyberloafing behaviors. }\end{array}$ & Accepted \\
\hline$H_{4}$ & $\begin{array}{l}\text { Group size is positively related to individual and group social loafing } \\
\text { behaviors. }\end{array}$ & Accepted \\
\hline $\mathrm{H}_{5}$ & $\begin{array}{l}\text { Task visibility is negatively associated with individual and group } \\
\text { social loafing behaviors. }\end{array}$ & Rejected \\
\hline$H_{6}$ & $\begin{array}{l}\text { Cyberloafing behaviors have a positive effect on individual social } \\
\text { loafing behaviors. }\end{array}$ & $\begin{array}{l}\text { Partially } \\
\text { accepted }\end{array}$ \\
\hline$H_{7}$ & $\begin{array}{l}\text { Group social loafing behaviors have a positive effect on individual } \\
\text { social loafing behaviors. }\end{array}$ & Accepted \\
\hline$H_{8}$ & $\begin{array}{l}\text { Group social loafing behaviors have a negative effect on group } \\
\text { satisfaction. }\end{array}$ & Accepted \\
\hline$H_{9}$ & $\begin{array}{l}\text { Individual social loafing behaviors have a negative effect on self- } \\
\text { evaluation. }\end{array}$ & Accepted \\
\hline$H_{10}$ & $\begin{array}{l}\text { Individual and group social loafing behaviors have a negative effect on } \\
\text { group assessment. }\end{array}$ & $\begin{array}{l}\text { Partially } \\
\text { accepted }\end{array}$ \\
\hline$H_{11}$ & $\begin{array}{l}\text { Group satisfaction has a mediating role in the relationship between } \\
\text { group social loafing behaviors and group evaluation. }\end{array}$ & Accepted \\
\hline$H_{12}$ & Group evaluation has a positive effect on self-evaluation. & Accepted \\
\hline
\end{tabular}




\section{Discussion, Conclusion and Implications}

In this study, social loafing, cyberloafing behaviors, self-evaluation and group evaluations in group work in higher education were examined in terms of gender, group size, and group formation. The effect of social loafing and cyberloafing behaviors exhibited by students in group work on individual and group evaluations was tested on the basis of the structural equation model. As a result of the research, hypotheses $\mathrm{H}_{2 \mathrm{a}}, \mathrm{H}_{2 \mathrm{~b}}, \mathrm{H}_{3}, \mathrm{H}_{4}, \mathrm{H}_{7}, \mathrm{H}_{8}, \mathrm{H}_{9}, \mathrm{H}_{11}$ and $\mathrm{H}_{12}$ were accepted, hypotheses $\mathrm{H}_{1 a}, \mathrm{H}_{1 b}, \mathrm{H}_{6}$ and $\mathrm{H}_{10}$ were partially accepted and hypothesis $\mathrm{H}_{5}$ was rejected.

With the partial acceptance of hypotheses $\mathrm{H}_{1 a}$ and $\mathrm{H}_{1 b}$, it was concluded that individual social loafing behaviors, cyberloafing behaviors and self-evaluation differed according to gender. While men's perception of individual social loafing and cyberloafing behaviors was higher, selfevaluation of group work was lower than that of women. There was no significant difference in terms of gender in terms of social loafing level of the group and group evaluation. Although there are many studies in the literature that indicate that men tend to display social loafing and cyberloafing behaviors more often (Karau \& Williams, 1997; Kerr, 1983; Doğan et al., 2012; Karadal \& Saygin, 2013; Tok, 2019), there are also studies indicating that there is no difference in terms of gender (Öneren et al., 2019). The difference determined in terms of loafing behavior can be explained by the fact that women are more disposed towards group work and have more responsibility (Tok, 2019). In terms of self-evaluation, this is parallel with the results showing that women tend to give themselves higher scores (Kaufman et al., 2000; Sherrard \& Raafat, 1994; Baker, 2008; Uyar et al., 2016). There are studies suggesting that there is no difference in selfevaluations in terms of gender (Mattheos et al., 2004). In terms of the validity of the assessment, it has been stated that there is a high correlation between the evaluation scores of university students and the teacher evaluation scores (Langan \& Wheater, 2003).

Hypotheses $\mathrm{H}_{2 \mathrm{a}}$ and $\mathrm{H}_{2 \mathrm{~b}}$, which examine the differentiation in terms of group formation, were accepted. In group work, differences in favor of student-created groups were determined in terms of individual and social loafing behaviors, self-evaluation and group evaluations among the individuals working in student-created groups and instructor-created groups. In the literature, there is no exact agreement in terms of this group formation. Some studies indicate that instructorcreated groups are fairer and more suitable for real life (Bacon et al., 2001; Blowers, 2003; Lam, 2015). It is suggested that the best group work takes place in instructor-created groups (Feichtner \& Davis, 1985; Felder \& Brent, 2001). Aggarwal \& O'Brien (2008) concluded that social loafing activity does not decrease in student groups. On the other hand, in student-created groups, homogeneity, productivity, performance, satisfaction and solidarity increase (Aggarwal \& O'Brien, 2008; Chapman et al., 2006; Hilton \& Philips, 2010; Strong \& Anderson, 1990) and social loafing behaviors decrease (Chidambaram \& Tung, 2005; Rajaguru et al., 2020). Similarly, Rajaguru et al. (2020) state that the effects of social loafing in student-created groups decrease through the students' efforts to pick up the slack of social loafers.

Hypothesis $\mathrm{H}_{3}$, which states that cyberloafing behaviors and individual social loafing behaviors are positively related was accepted. Only the updating and games / gambling sub-dimensions of individual social loafing and cyberloafing were low-correlated.

Hypothesis $\mathrm{H}_{4}$ was accepted as a result of the positive correlation between group size and individual and group social loafing behaviors. Group size, one of the important factors for social loafing, has been discussed in many studies. It has been concluded that as the groups get smaller, solidarity increases and social loafing decreases (Aggarwal \& O'Brien, 2008; Liden et al., 2004). In this respect, the findings support many research results. The negative relationship between selfevaluation and group evaluation and group size parallels the studies in the literature that conclude that small groups perform better both individually and in terms of the group (Hoegl, 2005; Ingham et al., 1974). In this context, although studies do not suggest an optimal group size to decrease social loafing, it is emphasized that working with small groups will be of benefit (Synott, 2016).

Hypothesis $\mathrm{H}_{5}$, which expresses the relationship between task visibility and individual and group social loafing behavior, was rejected. Accordingly, it can be said that there was no 
relationship between the students' perceived task visibility and their social loafing behavior. It is a surprising result that task visibility, which is one of the important factors for social loafing, was not related to loafing. Many studies have revealed that social loafing is negatively related to the visibility of the task by the manager or instructor (George, 1992; Liden et al., 2004; Simms \& Nichols, 2014). In addition, when individuals are lonely or as the group size decreases, they feel more visible and distinguishable and accordingly, their social loafing behavior decreases. In a limited number of studies, no relationship was found between task visibility and social loafing (Doğan et al., 2012; Piezon \& Ferree, 2008). This situation has been explained in some studies as that the importance of the task visibility factor decreases in societies that have gained collective consciousness in a cultural sense.

Among the hypotheses about testing the structural equation model, hypotheses $\mathrm{H}_{6}$ and $\mathrm{H}_{10}$ were partially accepted, while hypotheses $\mathrm{H}_{7}, \mathrm{H}_{8}, \mathrm{H}_{9}, \mathrm{H}_{11}$ and $\mathrm{H}_{12}$ were accepted. When the effect of cyberloafing behaviors on individual social loafing was examined, it was found that only the games / gambling sub-dimension had an effect on cyberloafing. This may be due to the fact that this type of cyberloafing is more frequently observed in group work. It was concluded that group social loafing behaviors had an effect on individual social loafing and group satisfaction. Similar to the literature, it can be said that the perception of group social loafing behaviors increases the tendency to display social loafing behaviors (Liden et al. 2004; Şeşen \& Kahraman, 2014). Liden et al. (2004) stated that group members are more prone to loafing when they suspect that the group is loafing. Perceptions of group social loafing decrease group satisfaction and decrease the efficiency and performance of group work (Duffy \& Shaw, 2000).

Regarding the self-evaluation of individual social loafing behavior, group social loafing behaviors have a negative effect on group evaluation. Accordingly, it can be said that individuals' perceptions of social loafing are determinative for their evaluations. On the other hand, it has been revealed that evaluations made in group work have a role in reducing social loafing (Aggarwal \& O'Brien, 2008). Making evaluations during group work is considered as a tool for early detection of problems within the group (Brooks \& Ammons, 2003; Dyrud, 2001; Pfaff \& Huddleston, 2003; Vik, 2001). In this context, evaluations in which social loafing behaviors are determinative are important for giving feedback in group work. Evaluations help to clarify the students' expectations, contributions and responsibilities in group work, and social loafing etc. provides compensation to group members who show inadequate performance due to various reasons. The members who do not participate in the group are given signs of the consequences (Aggarwal \& O'Brien, 2008). Considering the place of evaluation tools in group work, the effect of social loafing on evaluations should not be overlooked.

Group satisfaction has a positive effect on the evaluation of the group. It is also seen that group satisfaction has a mediating effect between group social loafing behaviors and group evaluation. Group evaluation was determined to have a positive effect on self-evaluation. Aslanoğlu (2017) observed a high-level, significant relationship between peer evaluation and self-evaluation in group work. In this context, it can be said that the performance of the group can be determinant in the self-evaluation of the individual. Of course, students' use of self-evaluation and group evaluation tools in group work will contribute in many ways such as taking responsibility for learning, motivation, and critical thinking.

As a result, in this study, the effect of individual and group social loafing behaviors perceived by individuals on self-evaluation and group evaluations in group studies was determined. Social loafing behaviors were analyzed in terms of gender, group size, task visibility, group formation and cyberloafing. While higher education students' social loafing behaviors were not found to be related to their task visibility, it was demonstrated that cyberloafing, group size, group formation and gender had a determining role. It was revealed that the social loafing behaviors of the group had an effect on the social loafing behaviors of the individual and that individual and group performances were affected by social loafing behaviors in group studies. In line with the findings of the study, suggestions can be made to minimize social loafing in group work which are 
frequently used in higher education. Lecturers should plan group work detailed and determine the size of the group in the optimum number suitable for the course. In addition, students should be allowed to choose the group members they will work with. It is known that social loafing behaviors have a determining role in the evaluation, as well as self and group evaluation have a preventive role on social loafing. In this respect, evaluating group work in a holistic manner using more than one assessment tool will increase the efficiency of group work. The research is important in terms of examining social loafing behaviors, self-evaluation, and group evaluations in the context of group work in higher education. However, the cross-sectional design of the study should be taken into consideration in terms of the generalizability of the results. The research was conducted with students at the level of higher education. In future studies, social loafing behaviors and related factors at different educational levels can be examined. Since the data of the study were collected through self-report scales, there may have been self-evaluation bias. Another limitation of the study is that the characteristics of the course, which may be determinant on social loafing behavior, could not be controlled. In this respect, it may be appropriate to consider social loafing behaviors in future studies together with many variables such as the characteristics of the course in which group work is conducted, the structure of the subject / content, and interest in the course. At the same time, social loafing behaviors can be examined in terms of group work carried out in technology-supported educational environments.

\section{References}

Aggarwal, P., \& O'Brien, C. L. (2008). Social loafing on group projects structural antecedents and effect on student satisfaction. Journal of Marketing Education, 30(3), 255-264. https://doi.org/10.1177/0273475308322283

Akbulut, Y., Dursun, Ö. Ö., Dönmez, O., \& Şahin, Y. L. (2016). In search of a measure to investigate cyberloafing in educational settings. Computers in Human Behavior, 55, 616-625. https://doi.org/10.1016/j.chb.2015.11.002

Albayrak, E., Ayas, T. \& Horzum, M. B. (2012). Examining social loafing behavior and groups work eligibility of university. Mehmet Akif Ersoy University Journal of Education Faculty, 12(23), 335 - 353.

Aslanoğlu, A. E. (2017). Assessment of the individual in a group: Peer and self-assessment. Boğaziçi University Journal of Education, 34(2), 35-50.

Bacon, D. R., Stewart, K. A., \& Anderson, E. S. (2001). Methods of assigning players to teams: A review and novel approach. Simulation \& Gaming, 32(1), 6-17. https:/ / doi.org/10.1177/104687810103200102

Baker, D. F. (2008). Peer assessment in small groups: A comparison of methods. Journal of Management Education, 32(2), 183-209. https://doi.org/10.1177/1052562907310489

Blowers, P. (2003). Using student skill self-assessments to get balanced groups for group projects. College Teaching, 51(3), 106-110. https://doi.org/10.1080/87567550309596422

Brooks, C. M., \& Ammons, J. L. (2003). Free riding in group projects and the effects of timing, frequency, and specificity of criteria in peer assessments. Journal of Education for Business, 78(5), 268-272. https://doi.org/10.1080/08832320309598613

Chapman, K.J., Meuter, M., Toy, D., \& Wright, L. (2006). Can't we pick our own groups? The influence of group selection method on group dynamics and outcomes. Journal of Management Education, 30(4), 557569. https://doi.org/10.1177/1052562905284872

Chidambaram, L., \& Tung, L. L. (2005). Is out of sight, out of mind? An empirical study of social loafing in technology-supported groups. Information Systems Research, 16(2), 149-168.

Çepni, S. (2008). Performanslarn değerlendirilmesi [Performance evaluation]. E. Karip (Ed.), Ölçme ve değerlendirme [Measurement and evaluation] (p. 194-239). Pegem Akademi.

Demir Uslu, Y., \& Çavus, M. (2014). Organizational justice and loafing behaviors. ODU Journal of Social Sciences Research, 4(9), 51-54.

Doğan, A., Bozkurt, S., \& Demir, R. (2012). A research about investigating the relationship between social loafing behavior and the perception of task visibility. The Journal of Social Economic Research, (24), 53-79.

Duffy, M. K., \& Shaw, J. D. (2000). The Salieri syndrome: Consequences of envy in groups. Small Group Research, 31, 3-23. https://doi.org/10.1177/104649640003100101

Dyrud, M. A. (2001). Group projects and peer review. Business Communication Quarterly, 64(4), 106-111. 
Ergün, E., \& Altun, A. (2012). The student's perspective of cyberloafing and its causes. Educational Technology Theory and Practice, 2(1), 36-53.

Feichtner, S. B., \& Davis, E. A. (1984). Why some groups fail: A survey of students' experiences with learning groups. Organizational Behavior Teaching Review, 9(4), 58-73. https://doi.org/10.1177/105256298400900409

Felder, R. M., \& Brent, R. (2001). Effective strategies for cooperative learning. Journal of Cooperation $\mathcal{E}$ Collaboration in College Teaching, 10(2), 69-75.

George, J. M. (1992). Extrinsic and intrinsic origins of perceived social loafing in organizations. Academy of Management Journal, 35(1), 191-202.

Hilton, S., \& Phillips, F. (2010). Instructor-assigned and student-selected groups: a view from inside. Issues in Accounting Education, 25(1),15-33. https://doi.org/10.2308/iace.2010.25.1.15

Hoegl, M. (2005). Smaller teams-better teamwork: How to keep project teams small. Business Horizons, 48(3), 209-214.

Ilgin, B. (2010). The roles of the emotional intelligence and leader member exchange in the occurrence of the organizational citizenship behaviors and its relationship with the social loafing (Doctoral dissertation). Hacettepe University, Institute of Social Sciences, Ankara.

Ilgın, B. (2013). A social disease: Social loafing. Uşak University Journal of Social Sciences, 6(3), 238-270.

Ingham, A. G., Levinger, G., Graves, J., \& Peckham, V. (1974). The Ringelmann effect: Studies of group size and group performance. Journal of Experimental Social Psychology, 10(4), 371-384.

Jassawalla, A., Sashittal, H., \& Sashittal, A. (2009). Students' perceptions of social loafing: Its antecedents and consequences in undergraduate business classroom teams. Academy of Management Learning $\mathcal{E}$ Education, 8(1), 42-54. https://doi.org/10.5465/amle.2009.37012178

Karadal, H., \& Saygin, M. (2013). An investigation of the relationship between social loafing and organizational citizenship behavior. Procedia-Social and Behavioral Sciences, 99, 206-215. https:// doi.org/10.1016/j.sbspro.2013.10.487

Karau, S., \& Williams, K. D. (1993). Social loafing: a meta-analytic review and theoretical integration Journal of Personality and Social Psychology, 65(4), 681-706. https://doi.org/10.1037/0022-3514.65.4.681

Karau, S. J., \& Williams, K. D. (1997). The effects of group cohesiveness on social loafing and social compensation. Group Dynamics: Theory, Research and Practice, 1, 156-168. http://dx.doi.org/10.1037/10892699.1.2.156

Kaufman, D. B., Felder, R. M., \& Fuller, H. (2000). Accounting for individual effort in cooperative learning teams. Journal of Engineering Education-Washington, 89(2), 133-140. https://doi.org/10.1002/j.21689830.2000.tb00507.x

Kerr, N. (1983). Motivation losses in small groups: a social dilemma analysis. Journal of Personality and Social Psychology, 45(4), 819-828.

Koç Erdamar, G., \& Demirel, H. (2010). Preservice teachers' perceptions of group work. Journal of Kirsehir Education Faculty, 11(3), 205-223.

Lam, C. (2015). The role of communication and cohesion in reducing social loafing in group projects. Business and Professional Communication Quarterly, 78(4), 454-475. https://doi.org/10.1177/2329490615596417

Langan, A. M., \& Wheater, C. P. (2003). Can students assess students effectively? Some insights into peerassessment. Learning and Teaching in Action, 2(1).

Latane, B., Williams, K., \& Harkins, S. (1979). Many hands make light the work: The causes and consequences of social loafing. Journal of Personality and Social Psychology, 37(6), 822-832. https://doi.org/10.1037/0022-3514.37.6.822

Liden, R. C., Wayne, S. J., Jaworski, R. A., \& Bennett, N. (2004). Social loafing: A field investigation. Journal of Management, 30(2), 285-304. https:// doi.org/10.1016/j.jm.2003.02.002

Lim, V. K. (2002). The IT way of loafing on the job: Cyberloafing, neutralizing and organizational justice. Journal of organizational behavior: The international Journal of Industrial, Occupational and Organizational Psychology and Behavior, 23(5), 675-694. https://doi.org/10.1002/job.161

Mattheos, N., Nattestad, A, Christersson, C., Jansson, H. \& Attstrom. R. (2004). The effects of an interactive software application on the self assessment ability of dental students. European Journal of Dental Education 8(3), 97-104. https:// doi.org/10.1111/j.1600-0579.2004.00325.x

Mulvey, P. W., \& Klein, H. J. (1998). The impact of perceived loafing and collective efficacy in group goal processes and group performance. Organizational Behavior and Human Decision Processes, 74, 62-87. https://doi.org/10.1006/obhd.1998.2753

Neuman, W. L. (2014) Social research methods: Qualitative and quantitative approaches. Pearson. 
Öneren, M., Demirel, E. N., Arar, T., \& Kartal, C. (2019). Investigating social loafing behavior in higher education institutes: A case of public university. Journal of Social Sciences of Mus Alparslan University, 7(1) 309-318 https://doi.org/10.18506/anemon.427913

Pfaff, E., \& Huddleston, P. (2003). Does it matter if I hate teamwork? What impacts student attitudes toward teamwork. Journal of Marketing Education, 25(1), 37-45. https://doi.org/10.1177/0273475302250571

Piezon, S. L., \& Ferree, W. D. (2008). Perceptions of social loafing in online learning groups: A study of public university and U.S. Naval War College students. International Review of Research in Open and Distance Learning, 9(2), 1-17. https://doi.org/10.19173/irrodl.v9i2.484

Rajaguru, R., Narendran, R., \& Rajesh, G. (2020). Social loafing in group-based learning: student-created and instructor-created group perspectives. Education+ Training, 62(4), 483-501. https://doi.org/10.1108/ET01-2019-0018

Schippers, M. (2014). Social loafing tendencies and team performance: the compensating effect of agreeableness and conscientiousness. Academy of Management Learning and Education, 13(1), pp. 62-81. https://doi.org/10.5465/amle.2012.0191

Sedikides, C., \& Strube, M. J. (1997). Self evaluation: To thine own self be good, to thine own self be sure, to thine own self be true, and to thine own self be better. In M. P. Zanna (Ed.), Advances in experimental social psychology, Vol. 29 (p. 209-269). Academic Press. https:// doi.org/10.1016/S0065-2601(08)60018-0

Sherrard, W. R., \& Raafat, F. (1994). An empirical study of peer bias in evaluations: students rating students. Journal of Education for Business, 70(1), 43-48.

Simms, A., \& Nichols, T. (2014). Social loafing: a review of the literature. Journal of Management Policy and Practice, 15(1), 58-67.

Sridharan, B., Tai, J., \& Boud, D. (2018). Does the use of summative peer assessment in collaborative group work inhibit good judgement?. Higher Education, 1-18. https://doi.org/10.1007/s10734-018-0305-7

Strong, J.T., \& Anderson, R.E. (1990). Free-riding in group projects: Control mechanisms and preliminary data. Journal of Marketing Education, 12(2), 61-67. https:/ / doi.org/10.1177/027347539001200208

Synnott, C. K. (2016). Guides to reducing social loafing in group projects: Faculty development. Journal of Higher Education Management, 31(1), 211-221.

Şeşen, H., \& Kahraman, C. A. (2014). The effect of coworkers' social loafing on indivıdual's job satisfactıon, organizational commitment and his own social loafing. Journal of Human and Work, 1(1), 43-51. https://doi.org/10.18394/iid.08880

Tabachnick, B. G., \& Fidell, L. S. (2013). Using multivariate statistics. Pearson.

Tok, T. N. (2019). The relationship between the perceptions of personality traits and social loafing behaviors of candidate teachers. Journal of Teacher Education and Educators, 8(1), 55-77.

Ugrin, J. C., Pearson, J. M., \& Odom, M. D. (2008). Profiling cyber-slackers in the workplace: Demographic, cultural, and workplace factors. Journal of Internet Commerce, 6(3), 75-89. https://doi.org/10.1300/J179v06n03_04

Uyar, Ş., Demir, K., \& Aksekioğlu, B. (2016). A triplet on performance-based assessment: Self, peer and rater assessments. International Journal of Turkish Education Sciences, 4(7), 69-80.

Ülke, H. E. (2006). Investigating the role of personality and justice perceptions on social loafing (Doctoral dissertation). Middle East Technical University, Ankara.

Vik, G. N. (2001). Doing more to teach teamwork than telling students to sink or swim. Business Communication Quarterly, 64(4), 112-119.

Yıldız, K. (2018). Political skill and social loafing behavior of university students, International Online Journal of Educational Sciences, 10(2), 59-80. https://doi.org/10.15345/iojes.2018.02.005 